\title{
Bioavailability of pollutants in bacterial communities of Rodrigo de Freitas Lagoon, Rio de Janeiro, Brazil
}

\author{
E.M. da Fonseca ${ }^{1}$, J.A. Baptista Neto ${ }^{1}$, J.J. McAlister ${ }^{2}$, B.J. Smith ${ }^{2}$, M.A.C. Crapez ${ }^{3}$ \\ ${ }^{1}$ Departamento de Geologia, Universidade Federal Fluminense, Niterói, RJ, Brazil. \\ ${ }^{2}$ School of Geography, Queen's University, Belfast, Northern Ireland, United Kingdom. \\ ${ }^{3}$ Laboratório de Microbiologia Marinha, Departamento de Biologia Marinha, Universidade Federal \\ Fluminense, Niterói, RJ, Brazil.
}

Submitted: May 8, 2013; Approved: March 14, 2014.

\begin{abstract}
Processes involving heavy metals and other contaminants continue to present unsolved environmental questions. To advance the understanding of geochemical processes that involve the bioavailability of contaminants, cores where collected in the Rodrigo de Freitas lagoon, and analyzed for bacterial activity and metal concentrations. Results would suggest an extremely reducing environment where organic substances seem to be the predominant agents responsible for this geochemical process. Analytical data showed sulphate reduction to be the main agent driving this process, since this kind of bacteria was found to be active in all of the samples analyzed. Esterase enzyme production did not signal the influence of heavy metals and hydrocarbon concentrations and heavy metals were found to be unavailable for biota. However, correlation between results for bacterial biomass and the potentially mobile percentage of the total $\mathrm{Ni}$ concentrations would suggest a negative impact.
\end{abstract}

Key words: heavy metals fraccionament, bacterial communities, sediment cores.

\section{Introduction}

Estuarine and coastal areas are often regions of high population density and intense human activity. As a result, elevated levels of contaminants in intertidal sediments collected from areas that have been seriously impacted by urban development are well documented (Cui et al., 2005; Rattan et al., 2005). Rio de Janeiro coastal environments are continually being impacted by anthropogenic activities that cause marine sediments to be contaminated by persistent pollutants such as heavy metals and hydrocarbons.

Sediments provide an important record of past pollution events as well as an important sink for heavy metals (Kruopiene, 2007; Rauf et al., 2009; Kim et al., 2011), and other pollutants such as hydrocarbons (Perra et al., 2009). Their continuous accumulation provides a potential source of contaminants that will eventually have a negative impact on aquatic biota (Pérez et al., 2006).

Few articles dealing with the influence of pollutants in bacterial communities are available in the literature, even simple studies of short duration and low cost are rare (Baum et al., 2003). Considering the basic position of bacterial communities in the trophic chain, toxicity tests involving bacteria represent an effective way to diagnose possible pollution impacts on the health of the environment. The main advantages of these analyses are the fact that they provide a fast and easy way of measuring the influence of environmental parameters on the behavior of bacterial communities (Baum et al., 2003).

Heavy metals can influence bacterial behavior in many ways. These microorganisms can produce enzymes that act as biological catalysts to allow different reactions and metabolic processes during organic matter decomposition. They also produce essential composites that are essential to microorganisms and plants (Moreno et al., 2003).

Bacterial enzymes are well known efficient indicators of environment disturbance that are a result of anthropogenic activities, when compared to the analyses of animal and vegetal species (Hinojosa et al., 2004). 
Heavy metals can inhibit the enzymatic interaction of complex substances, for example, they may destroy enzyme proteins and interact with other active sites (Megharaj et al., 2003). They also influence microbial activity, whereby, biogeochemical processes that take place in soils and sediments may become neutralized (Duran et al., 2008).

Polycyclic aromatic hydrocarbons (PAH's) are ubiquitous pollutants and their environmental behavior has been investigated for more than 30 years (Perra et al., 2009). They have been detected in water, soils, sediments, aquatic organisms and food (Khairya et al., 2009). PAH's introduced into the marine environment are strongly bound by sediments due to their low water solubility and hydrophobic nature (Perra et al., 2009). Consequently, very high concentrations of PAH's have been recorded in coastal sediments near urban and industrial cities (da Silva et al., 2007). Due to their toxicological characteristics, scientists have mainly focused on their effects on bacterial communities (Sun et al., 2012).

The impact resulting from the accumulation of pollutants in coastal zones can increase considerably in more restricted hydrodynamic environmental conditions, such as estuaries and coastal lagoons where concentrations of fine sediment and organic matter are high (Perra et al., 2009). Sediments along the coastline of southeast Brazil have shown markedly increased levels of pollution over the past seventy years due to rapid economic growth (Pereira et al., 2007). The present study was carried out in Rodrigo de Freitas Lagoon, located in an extremely urbanized zone of Rio de Janeiro and it is considered to be one of the most polluted coastal lagoons in SE Brazil. This research studied the relationship between several geochemical components of the water body in an attempt to verify the possible influence that heavy metals and hydrocarbons may have on the development of existing bacterial communities in the sediments present in this environment.

\section{Studied area}

The Rodrigo de Freitas lagoon, located in the southern area of Rio de Janeiro (22057'02' S; 043011'09' W, Figure 1) has a perimeter of $7.5 \mathrm{~km}$. Over the past twenty years this lagoon has reduced in area by $1.4 \mathrm{~km}^{2}$ (present water mirror surface is $2.4 \mathrm{~km}^{2}$ ) and by approximately $3 \mathrm{~m}$ in depth during the last century (SEMADS, 2001). The greatest depth of $11 \mathrm{~m}$ was recorded in the southern part of

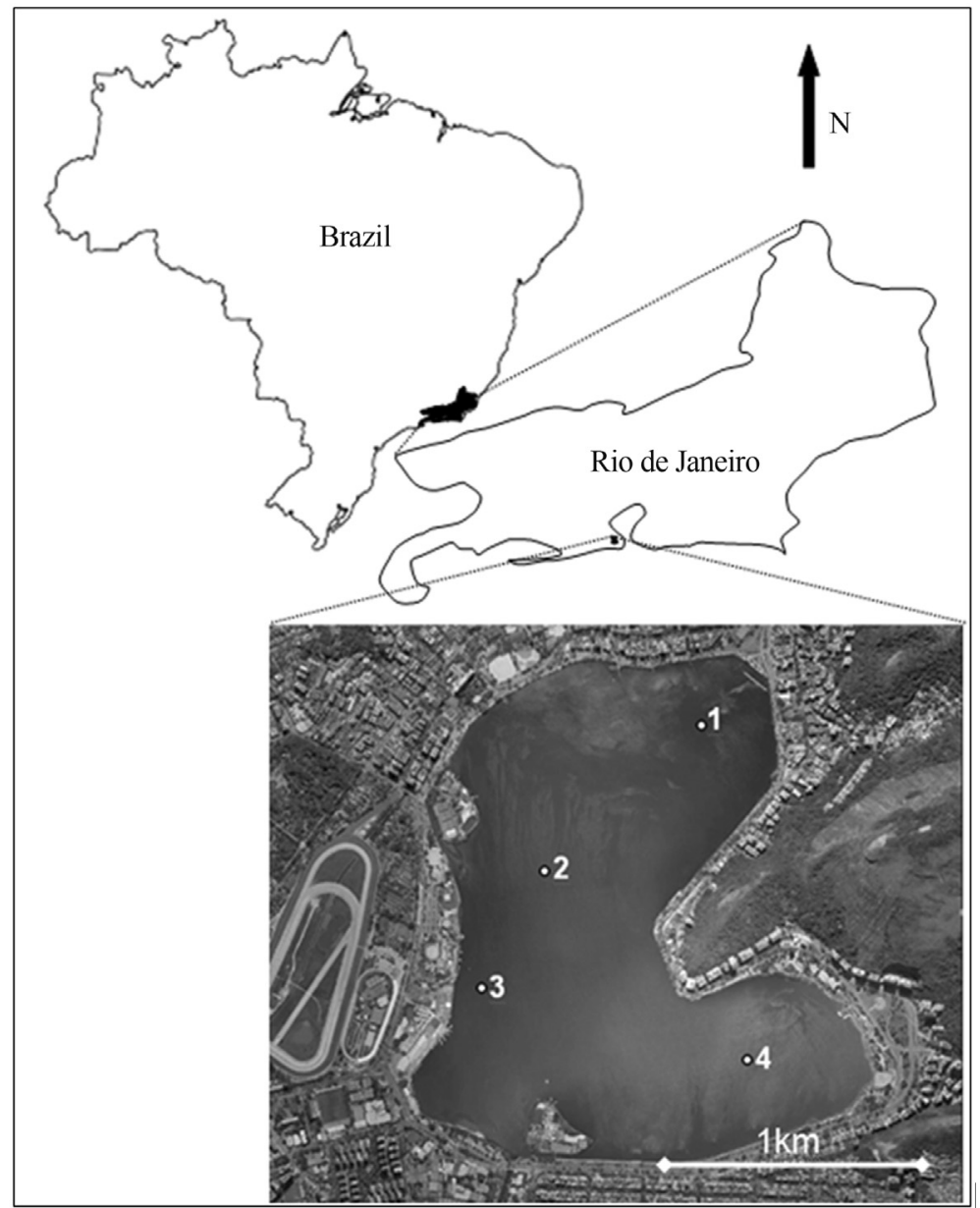

Figure 1 - Study area and sampling stations localization. 
the lagoon (Andreata et al., 2001). The Rodrigo de Freitas is the most urbanized lagoon in Rio de Janeiro and its only connection with the sea is via the $850 \mathrm{~m}$ Jardim de Ala Channel that frequently becomes silted with marine sediments. The lagoon is a semi-confined system making water renewal complex and the marine water flux is superficial, leaving deeper layers unaffected (Torres, 1990). The fresh water input comes primarily from the Macacos River, but a small amount also comes via the Cabeça and Rainha Rivers (Andreata et al., 2001). Extreme reducing conditions within the lagoon are due to the high concentration of organic matter, low currents and limited exchanges with the sea, making ideal conditions for the accumulation of pollutants (Kim et al., 2011). This coastal lagoon represents a transition between fresh and salt water that leads to a gradual variation in the amount of dissolved salt flocculation. Pollutants adsorbed by suspended matter tend to settle out and become deposited in the bottom sediments. Other more stabilized compounds may be formed as a result of, for example, complexation reactions.

A densely urbanized area that surrounds the lagoon is responsible for a large input of pollutants to its main tributary rivers and pluvial water galleries. Previous study recorded total metal concentrations as being significantly in excess of their background levels (Loureiro, 2009). Urbanization has caused the border of the lagoon to be filled with soil run-off from shanty towns. This has resulted in a decrease in area and an increase in organic pollutants and these parameters along with poor water circulation have caused severe anaerobic conditions within the lagoon (Brito and Lemos, 1982).

This lagoon is used for leisure purposes and is surrounded by streets with intense traffic conditions and highrise buildings. It is also close to the Tijuca National Park. It is undergoing treatment through the efforts of the local government to remove organic material from the surface (which will increases dissolved oxygen) and to recover the edges using mangrove vegetation. Factors like high organic matter concentration in the sediments and low hydrodynamics have caused an extremely reducing environment in this lagoon and this makes it a very interesting environment to carry out geochemical studies.

\section{Materials and Methods}

Core samples ( $1 \mathrm{~m}$ length) were collected from four different stations using PVC tubes. Both ends of the tubes were sealed under water before removal to avoid oxidation of the sample. The tubes had sampling holes drilled at 10 $\mathrm{cm}$ intervals and hermetically sealed to avoid oxidation reactions. $\mathrm{pH}$ and temperature measurements were carried out using a Metrohm 744 meter and Eh measurements employed a Analion, ROX 673 meter whereby electrodes were inserted into the sampling holes and results were recorded in the field. The first core was used to analyze biological parameters which included, Electron Transport System Ac- tivity (ETSA), Esterase Enzyme Concentrations (ESTE), Bacterial Organic Carbon (BOC) and protein, carbohydrate and lipid concentrations. These subsamples where stored in plastic bags and placed in cool boxes to maintain the original temperature. The other cores were immediately transported to the laboratory and frozen. After a period of days the cores were removed and placed in a glove box under an inert atmosphere of nitrogen and sampled for analysis. Samples were freeze dried and passed through a $2 \mathrm{~mm}$ diameter nylon mesh sieve. The $<63 \mu \mathrm{m}$ fraction was collected by further sieving a representative portion of the $<2 \mathrm{~mm}$ fraction through a nylon mesh. The $<63 \mu \mathrm{m}$ fraction was analyzed for total organic carbon, polyaromatic hydrocarbons (PAH's) and total heavy metals plus their phase fractionation patterns (Selective extraction). Particle size analysis of the $<63 \mu \mathrm{m}$ fraction was carried out using a Malvern 2600LC laser analyzer after removing organic matter. Oxidizable organic carbon employed the Walkley and Black method (Walkley and Black, 1982) and polycyclic aromatic hydrocarbons (PAH's) were determined using a mass spectrometer technique (Tronczynski et al., 2005).

Total biopolymers (carbohydrates, lipids and proteins) were analyzed in triplicate by extraction from wet sediment samples and using a spectrophotometric method. Carbohydrates (CHO) were quantified according to Gerchacov and Hachter (1972) using the same principle as Dubois et al. (1956). Lipids (LIP) were extracted using a mixture of chloroform and methanol and analyzed according to the Marsh and Wenstein method (Marsh and Weinstein, 1966) using tripalmitine as a standard. Proteins (PTN) were determined using the Hartree (Hartree, 1972) method, which was modified by Rice (Rice,1982) to compensate for the interference of phenol. Bovine albumin, fraction $\mathrm{V}$ (Sigma), was used as a standard. Lipids, carbohydrates and proteins were converted into carbon equivalents using 0.75 , 0.40 and 0.49 g.C $\mathrm{g}^{-1}$ conversion factors respectively (Gerchacov and Hatcher, 1972).

The biopolymeric carbon fraction (C-BPF) was defined as the sum of carbohydrate, protein and lipid carbon (Fabiano and Pusceddu, 1998). Total bacterial carbon (BOC) was calculated using epifluorescent microscopy (Axiosp 1, Zeiss, triple filter Texas Red - DAPI - fluorescein isothiocyanate, $1.000 \mathrm{X}$ magnification) and fluorochrome fluorescein diacetate (Kepner and Pratt, 1994). Carbon biomass $\left(\mathrm{mg} \mathrm{C} / \mathrm{cm}^{3}\right)$ was determined using the method described by Carlucci et al. (1986). Fluorochrome fluorescein diacetate allows the score of viable cells to be morphologically differentiated as cocci, rods and spirilla. Esterase enzyme activity (EST) was determined using fluorogenic compounds that are enzymatically transformed into fluorescent products by enzymes that hydrolyze many polymeric biomolecules and quantified by emission spectrophotometery (Stubberfield and Shaw, 1990). Results are expressed in $\mathrm{mg}$ fluorescein $/ \mathrm{h} / \mathrm{g}$ of sediment. Electron 
transport system activity (ETSA) was determined using the method described by Houri-Davignon and Relexans (1989), without a surplus of electron donors (Trevors, 1984). It is based on dehydrogenase enzymes, which are the major products of oxidoreductase reactions. They catalyze the oxidation reactions that take place in these substrates and produce electrons that can enter into the electron transport system of the cell that are quantified using a UVvisible spectrophotometric absorption technique. Results are expressed in $\mathrm{mL} \mathrm{O} / \mathrm{h} / \mathrm{g}$ of sediment.

The selective extraction protocol (McAlister et al., 2005) is shown in Table 1 and in this study the extraction of the organic phase was modified. This technique offers a differential approach, whereby those operationally defined solid phases that bind these metals is examined. It provides a better understanding of metal retention and bioavailability under different environmental conditions and provides additional information to enhance analytical interpretation (McAlister et al., 2005; Pereira et al., 2007).

Samples were weighed into acid washed polyproplene tubes and the extracts were collected in acid washed HDPE tubes prior to analysis. Reference material is not available to allow quality control monitoring of selective extraction techniques. Reproducibility was monitored by including sample blanks and repeating sample analysis at regular intervals. Analytical standards were prepared by diluting a $1000 \mathrm{mg} / \mathrm{L}$ BDH stock solution that is traceable to the NIST Certified Reference Institute. All standards were diluted to volume in the extracting solutions used for the selective extractions so that both samples and standards were matrix matched.

$\mathrm{Cu}, \mathrm{Cr}, \mathrm{Ni}, \mathrm{Pb}$ and $\mathrm{Zn}$ concentrations were analyzed using a Perkin Elmer AAnalyst 3100 atomic absorption spectrophotometer. The residual phase was dissolved using a Perkin Elmer microwave digestion system and analytical accuracy was monitored using a certified reference material (I.G.G.E., stream sediment, China). Chloride and sulphate analyses were carried out using a Dionex DX-500 Ion Chromatography system. The detection limit for $\mathrm{Cu}, \mathrm{Pb}$, $\mathrm{Zn}, \mathrm{Cr}$ and Ni were $0,05 \mathrm{mg} / \mathrm{kg} ; 0.1 \mathrm{mg} / \mathrm{kg} ; 0.01 \mathrm{mg} / \mathrm{kg}$; $0.05 \mathrm{mg} / \mathrm{kg}$ and $0.04 \mathrm{mg} / \mathrm{kg}$, respectively.

Data were divided into four groups and statistical analysis was carried out using the Kruskal-Wallis test. This is an analysis of variance procedure that assumes the null hypothesis, whereby all samples have identical distributions. Spearman's rank correlation coefficient (r) was computed on the ranks of the data instead of actual values. A p-value of 0.05 was used and values below this were considered significant (Helsel and Hirsch, 1992). Statistical analyses were carried out using the soluble phase concentrations.

\section{Results}

The toxicity of many chemicals is related to their $\mathrm{pH}$ in solution and at high chemical concentrations, to osmotic imbalance (Jennings et al., 2001). In the present study, porewater $\mathrm{pH}$ was relatively constant for all the sediment cores (pH 7.38-8.2) (Figure 2). These values are consistent with the literature (Burton et al., 2003). Hundreds of $\mathrm{pH}$ measurements were done in estuarine and marine sediments and never found $\mathrm{pH}$ values outside the range of $\mathrm{pH} 6$ to 8 (Berner, 1981).

Temperature is one of the most important environmental parameters that affect the metabolism of organisms. The metabolism of organisms reacts to temperature effects exponentially, reaching a peak (at optimum temperature metabolism) and then experiencing a rapid decline in heterotrophic capacity (Cunha-Santino and Bianchini Júnior, 2010). In the present study the temperature data recorded showed values ranging from between 22.1 ${ }^{\circ} \mathrm{C}-24.5{ }^{\circ} \mathrm{C}$ and these tended to increase with depth (Figure $2 \mathrm{C}$ ).

Redox conditions can influence trace metal behavior in sediments either directly or indirectly through a change in the oxidation state of a ligand capable of complexing the metal (Burton et al., 2003). Eh values are very important when it comes to understanding the dynamic processes involved in the production and consumption of oxygen in water columns and for studying the hydrologic behavior of aquatic environments (Reddy et al., 2000). When $\mathrm{O}_{2}$ is exhausted in the water column as a result of organic matter degradation, other electron acceptors (nitrate, nitrite, iron, manganese oxides, sulfate and carbon dioxide) that depend on Eh conditions are used in further decomposition reactions (Reddy et al., 2000). Together with Eh, particle size analyses indicated a low hydrodynamic environment and a high potential for pollution accumulation. The particle size

Table 1 - Methodology of analysis of heavy metals.

\begin{tabular}{lccc}
\hline Phase/extractant & Ratio & Time & Conditions \\
\hline Water-soluble deionised water & $1: 20$ & $2 \mathrm{~h}$ (leave overnight) & Shaking \\
Exchangeable/carbonate $1 \mathrm{M} \mathrm{NH}_{4} \cdot \mathrm{OAc}(\mathrm{pH} 5)$ & $1: 50$ & $6 \mathrm{~h}$ & Shaking \\
Amorphous $\mathrm{Fe} / \mathrm{Mn} 0.25 \mathrm{M} \mathrm{NH}_{2} \cdot \mathrm{OH} \cdot \mathrm{HCl} / 0.25 \mathrm{M} \mathrm{HCl}$ & $1: 50$ & $2 \mathrm{~h}$ & $600^{\circ} \mathrm{C}$ \\
Crystalline $\mathrm{Fe} / \mathrm{Mn} 1 \mathrm{M} \mathrm{NH}_{2} \cdot \mathrm{OH} \cdot \mathrm{HCl} / 25 \% \mathrm{CH}_{3} \mathrm{COOH}$ & $1: 50$ & $3 \mathrm{~h}$ & $90^{\circ} \mathrm{C}$ \\
Organic $\mathrm{HNO}_{3} / \mathrm{HCl}(3: 1)$ & $1: 50$ & $1 \mathrm{~h}$ & $90^{\circ} \mathrm{C}$ \\
Residual/Siliceous $\mathrm{HNO}_{3} / \mathrm{HF} / \mathrm{HCl}(3 / 1 / 0.5)$ & $0.1: 25$ & $20 \mathrm{~min}$ & Microwave Digestion \\
\hline
\end{tabular}


$\mathrm{pH}$

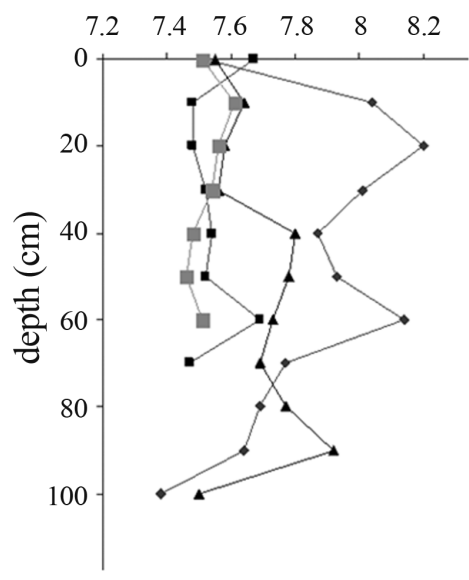

Core1
Eh (mv)

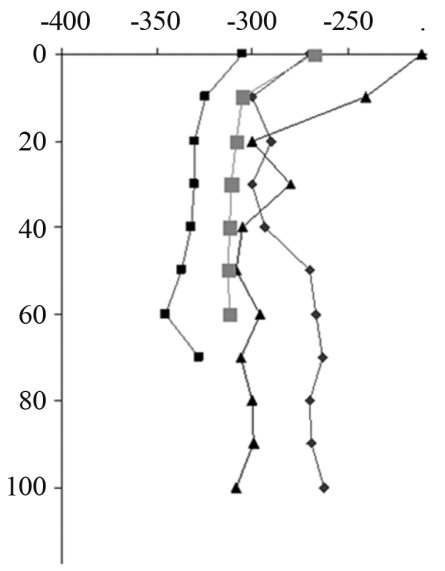

Core 2
Core 3

\section{Temperature $\left({ }^{\circ} \mathrm{C}\right)$}

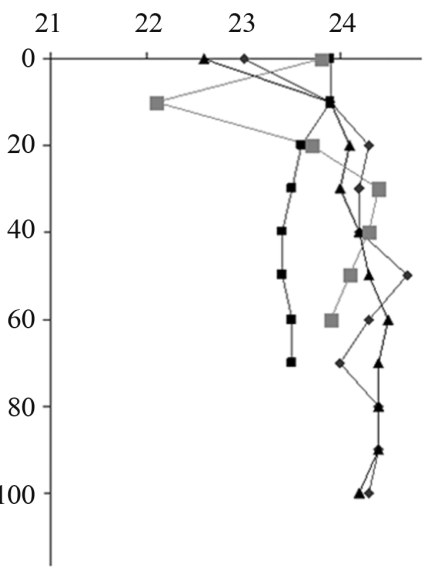

Core 4

Figure 2 - Physico-Chemical results in the cores (variation $\mathrm{x}$ depth).

pattern of the lagoon revealed the predominance of mud (with an average of $90.3 \%$ below $63 \mu \mathrm{m}$ and $24.2 \%$ below $2 \mu \mathrm{m})$.

In the present study, bacteria activity was measured throughout the Electron Transport System Activity (ETSA). ETSA values ranged between $0.003 \mu \mathrm{L} \mathrm{O} / \mathrm{h} / \mathrm{g}$ and $0.226 \mu \mathrm{L} \mathrm{O} / \mathrm{h} / \mathrm{g}$ and would suggest an active metabolism with respect to the bacterial communities in the sediments (Figure 3). Bacterial activity and biomass are generally higher near the surface sediment and decrease with depth (Fischer et al., 2002). In the present study no depth variation pattern was identified and esterase enzymes were found to be active in all 20 samples. The higher values were recorded in the surface samples $(2.261 \mathrm{mg}$ fluoresceine $/ \mathrm{h} / \mathrm{g})$ and the lower at $20 \mathrm{~cm}$ depth $(0.284 \mathrm{mg}$ fluoresceine $/ \mathrm{h} / \mathrm{g}$ ), both samples were collected at station 4 . The average concentration recorded was 1.244 ug fluoresceine $/ \mathrm{h} / \mathrm{g}$.

The bacterial organic carbon values ranged between 1.305 and $3.145 \mu \mathrm{g} \mathrm{C} / \mathrm{cm}^{3}$, with the lowest being found at $60 \mathrm{~cm}$ depth, in a sample taken from station 3 , and the highest, at $80 \mathrm{~cm}$, in a sample collected from station 4 . Like the other biologic parameters, BOC values did not show any variation pattern with depth (Figure 3).

According with some authors (Fischer et al., 2002) bacterial populations tend to concentrate in surface sediments to reflect high mineralization rations and then tend to decrease with depth. However, the bacterial numbers do not necessarily reflect the bacterial communities' situation, in terms of metabolic activity or bacterial cell production

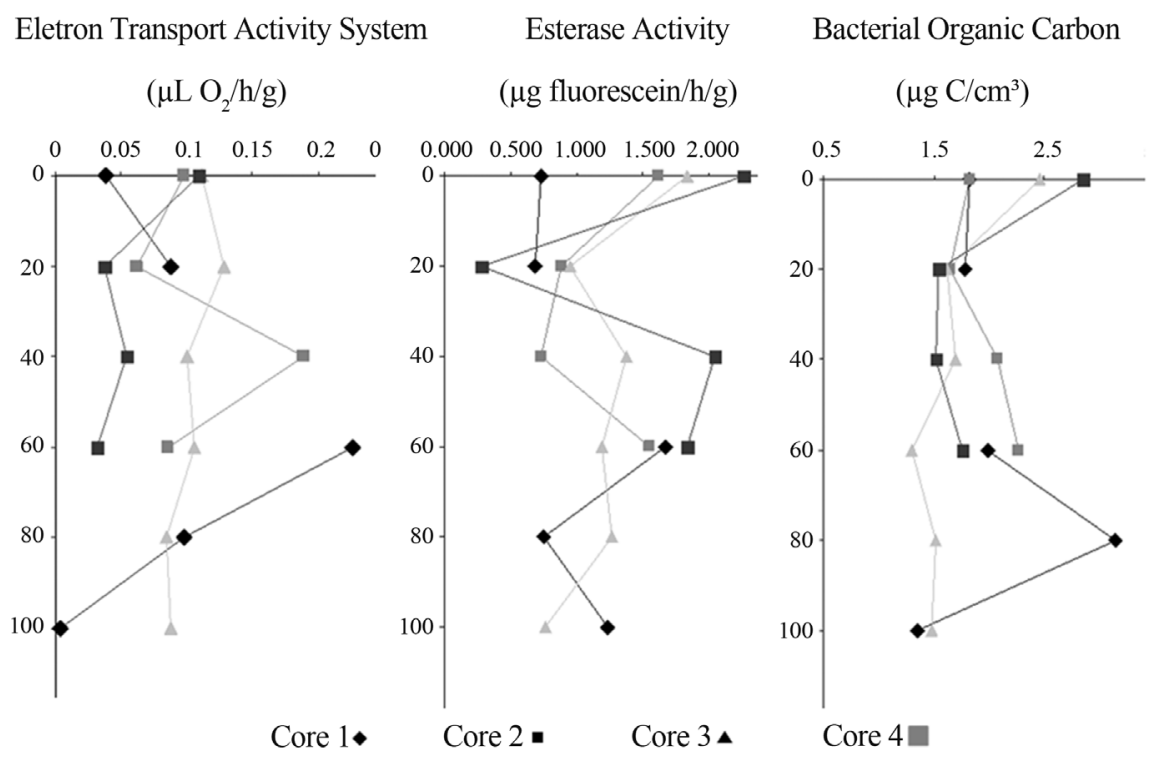

Figure 3 - Biologic parameters variation in the cores (variation x depth). 
(Haglund et al., 2002). Viable bacteria are found even in deeper sediment layers (Miskin et al., 1998), however, variation in the bacterial metabolic state with depth is still not well understood (Haglund et al., 2003).

The average biopolymer concentrations recorded in the samples collected from the Rodrigo de Freitas lagoon was $1.49 \mathrm{mg} \cdot \mathrm{g}^{-1}$. Carbohydrates represented $66.6 \%$ of the total biopolymers found in the surface sediments, followed by lipids (26\%) and proteins (7.4\%). The representative biochemical concentrations found in the surface sediments do not follow those found in the literature. Some authors found the relationship to be carbohydrates $>$ proteins $>$ lipids (Dell'Anno et al., 2002).

Total organic carbon results show an enrichment with values being higher than those found in other similar environments, such as an estuarine region in southeast Queensland, Australia (Burton et al., 2003), where the Eh values ranged between $+120 \mathrm{mV}$ and $+260 \mathrm{mV}$. With the exception of the first's layers in a sample from station 2, values showed a decreasing pattern with depth (Figure 2).

Sediment cores have been used to assess hydrocarbon pollution history in industrialized countries such as the USA (Macdonald et al., 2005), but not in tropical South American countries (Cavalcante et al., 2009). In the present study, PAH concentrations ranged from below detection levels to $10.67 \mu \mathrm{g} . \mathrm{g}^{-1}$ in samples from station 1 down to $1 \mathrm{~m}$ depth. It was found values of $11.8 \mu \mathrm{g} . \mathrm{g}^{-1}$ for PAH's in an estuarine lagoon in the south of Brazil, located near an oil refinery (Medeiros et al., 2005). Comparing the present work to the global context, Rodrigo de Freitas lagoon sediments reached levels comparable to those found in the contaminated mangroves of Hong Kong (6.19 $\left.\mu \mathrm{g} . \mathrm{g}^{-1}\right)$ (Tam et al., 2001).

Copper, lead and zinc concentrations showed an enrichment pattern in the surface layers suggesting the presence of significant sources for these heavy metals. In contrast, $\mathrm{Cr}$ and $\mathrm{Ni}$ concentrations showed homogeneous values along the sediment cores. According to many authors, the soluble/exchangeable phase is the most mobile and bioavailable phase for heavy metals, present in soils and sediments (Magrisso et al., 2008). In the present work, all heavy metals were below their detection limits in the soluble phases and would suggest that they are not available for uptake by the biota.

\section{Discussion}

There are many studies in the literature about heavy metal toxicity in bacterial communities and its relationship with physic-chemical sediment properties (Silva et al., 2012; Vishnivetskaya et al., 2011). These studies are generally indicative of the major effects of heavy metals in fine grain sediments that contain high concentrations of organic matter (Eggleton and Thomas, 2004). However, in a number of cases it is not possible to establish a relationship be- tween the adverse effects of heavy metals and parameters such as $\mathrm{pH}$, grain size and organic matter concentration (Haanstra and Doelman 1991) and this may be due to the difficulty of reproducing similar environmental conditions in bioassay samples (Apitz et al., 1999).

Many references indicate the direct influence of bacterial communities on environmental physico-chemical conditions. Some authors described biofilms under a reducing environment as the best way to establish ideal physico-chemical conditions, especially when studying sulphate reducing bacteria (Ahimou et al., 2007). However, microorganisms can mobilize or immobilize metals, metalloids or organometallic compounds through reducing or oxidizing processes (Vu et al., 2009). On the other hand, the present work did not show any significant relationship between bacterial biomass, $\mathrm{pH}$ and Eh values (Table 2).

In the case of temperature, correlation analysis showed a significant result for organic bacterial carbon $(p=0.04)$. According to the literature (Corseuil and Alvarez, 1996; Cunha-Santino and Bianchini Júnior, 2010), temperature is one of the main parameters to influence microorganism activity and survival. The same authors suggested that lower temperatures decrease cell wall fluidity and permeability, which controls the nutrient and contaminant transport through the microbial cell. High temperatures are associated with higher enzymatic activity and an increase in the level of biodegradation. However, an excessive increase in temperature above an ideal point can interrupt enzymatic activity (Corseuil and Alvarez, 1996).

It is necessary, however, to consider the small range of variation in temperature recorded in the present study. It was found similar results, whereby a small variation in temperature range produced a significant influence on the bacterial processes (Gsell et al., 1997). Total organic carbon showed a direct correlation with $\mathrm{Cu}$ and $\mathrm{Zn}$ concentrations $(p=0.02)$ and would indicate the ability of organic matter to form organometallic complexes (Celis et al., 2000), especially with $\mathrm{Cu}$.

PAH concentrations did not show a significant correlation with biologic parameters and this may be due the high concentrations of organic matter found in the Rodrigo de Freitas lagoon sediments. Simple organic molecules are easier metabolized and are preferentially used by bacterial communities, proving that molecular structure has a higher influence on the ability of microorganisms to metabolize this compound. Low molecular weight hydrocarbons like alcohols are easier to metabolize. Another determinant factor is the potential oxidation of the available acceptors present in the environment. In anoxic sediments, mineralization occurs via fermenters and anaerobic bacteria that use nitrate, iron sulphate or carbon dioxide as electron acceptors. These are generally inefficient processes and the bacteria involved in these processes are more restrictive with the carbon substrate that can be used (Wellsbury et al., 1996). Several studies have shown fewer sulphates to be produced 


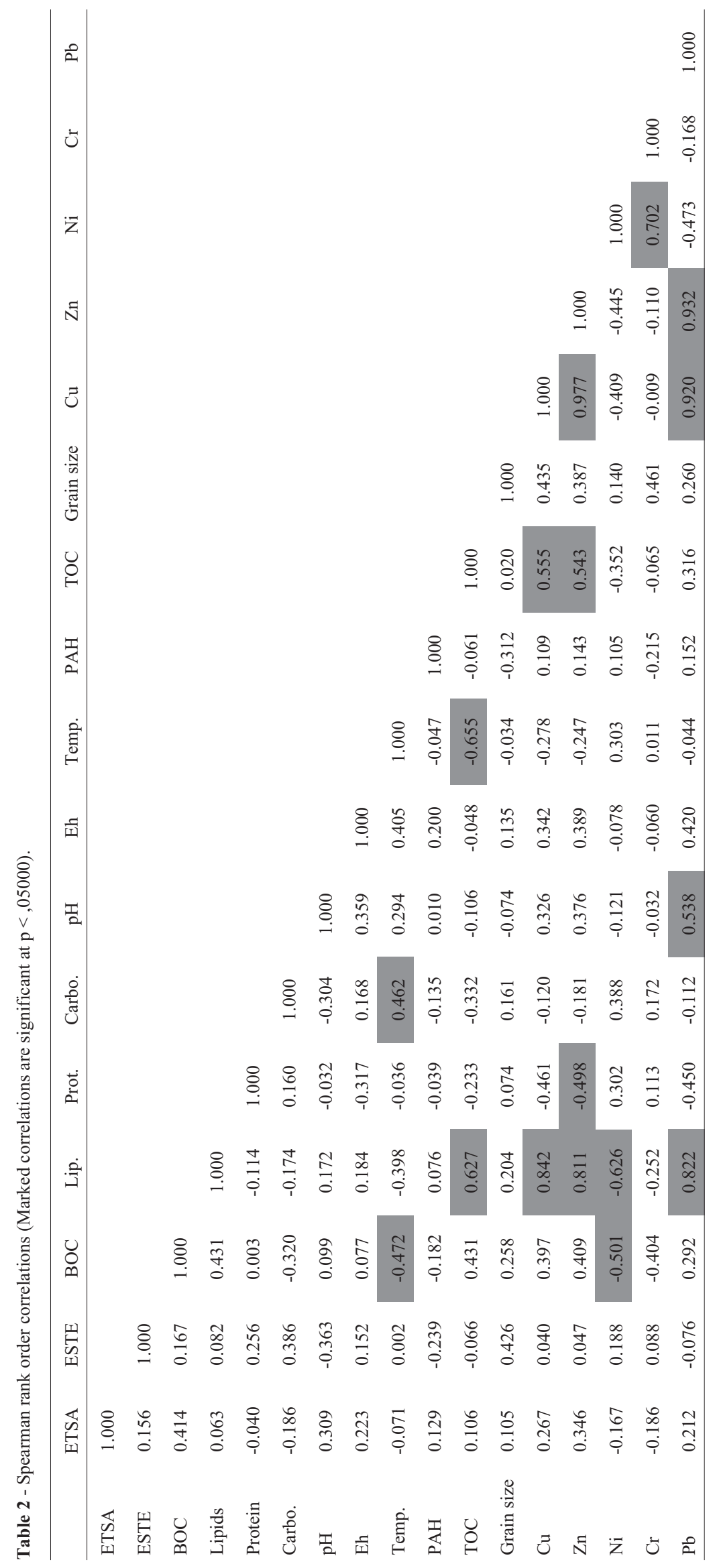


by organic complexes in natural substrates (Gilbert et al., 2003). It is well known that sulphate-reducing bacteria can metabolize a limited number of organic substrates (Chang et al., 2000). This sulphate reducing process is carried out by a complex system composed of an independent community of anaerobic organisms, where each species promotes the mineralization of a particular part of the organic complex substrate (Chang et al., 2000). In this way, cooperation between the different species is necessary. Sulphate reduction is possible by the utilization of easier assimilation electron donors (Kolmert and Johnson, 2001).

In general, the kinetics of hydrocarbon oxidation is faster for electron acceptors with a higher potential for oxidation (Corseuil and Alvarez, 1996). Sulphates have a lower capacity when compared to others acceptors. Since this compost is the main electron acceptor present in the Rodrigo de Freitas lagoon sediments, the process of decomposition of hydrocarbons is slower.

According to the literature (Nweke and Orji, 2009), the toxicology of heavy metals on bacterial communities is a result of enzyme neutralization and this depends on the concentration of heavy metals that can stimulate enzyme production as a form of protection. Bacteria can protect themselves from the toxic effect of heavy metals by producing a gel containing $95 \%$ or more of water and a matrix containing exopolysaccharidic substances (EPS) (Videla and Herrera, 2005). Bacteria secretes extracellular enzyme esterase to decompose biopolymers in monomers that compose the biofilms. The interaction of acidic groups that are present in the biofilms, with metallic ions reduces the toxicity of the microenvironment to allow microbial growth. According to some authors (Ortega-Morales et al., 2007), the development of biofilms in copper leagues is favored by the production of exopolymers.

Many studies use enzymes as indicators with respect to metal bioavailability. Ram et al. (2000) verified a negative influence of $\mathrm{Ni}$ on organic matter degradation in anoxic sediments. Viret et al. (2006) recorded a decrease in the amount of oxygen consumed by the bacterial community when they added $\mathrm{Ni}$ in an oxygenated solution. In the present study there was no correlation found between the exoenzymes and heavy metal concentrations. However, even though Ni was not found in the soluble phase of these sediments, correlation data for the potential bioavailability of this metal and the bacteria biomass indicated a possible negative influence of $\mathrm{Ni}$ on the growth of the bacteria community in the lagoon sediments $(p=0.04)$.

\section{Conclusion}

Pollutants like heavy metals must be studied due to the risks they present to the aquatic environment and human health. Results would indicate that the main respiratory process in the sediments of Rodrigo de Freitas Lagoon is due to the reduction of sulphates. Low energetic efficiency plus low hydrodynamics and the presence of fine grain deposits in the lagoon can explain the accumulation of organic matter in the sediments.

Chemical analyses show an enrichment pattern for the heavy metal concentrations, especially $\mathrm{Cu}, \mathrm{Pb}$ and $\mathrm{Zn}$ in the surface layers and would suggest the presence of significant sources of these heavy metals. On the other hand, the elements $\mathrm{Cr}$ and $\mathrm{Ni}$ showed homogeneous values along the sediment cores and heavy metal fractionation was predominate in the organic phase. The concentration of metals found in the soluble phase of the sediments was all below their detection limits and this would suggest that they were biologically unavailable.

No correlation between the metals extracted from the mobile phase and the esterase enzymes concentrations were found, despite of the significant negative correlation between the Ni concentrations and the bacterial biomass development. This study provides one more step to help us understand pollutant dynamics in the Rodrigo de Freitas Lagoon. However, it also showed that field biochemical characterization is not enough. More bioassay studies are necessary to gain a better understanding of the heavy metal and hydrocarbons influence in this environment.

\section{References}

Ahimou F, Semmens, MJ, Haugstad G, Novak PJ (2007) Effect of protein, polysaccharide, and oxygen concentration profiles on biofilm cohesiveness. Appl Environ Microbiol 73:2905-2910.

Andreata JV, Marca AG, Soares CL, Santos RS (1997) Distribuição mensal dos peixes mais representativos da Lagoa Rodrigo de Freitas, Rio de Janeiro, Brasil. Rev Bras Zool 14:121-134.

Apitz SE, Arias E, Clawson AS, Lin EW, Melcher RJ, Hemmingsen BB (1999) The development of a sterile, PAH-spiked, aged marine sediment for biodegradation experiments: Chemical results. Org Geochem 30 891-900.

Baum C, Linweber P, Schlichting A (2003) Effects of chemical conditions in re-wetted peats temporal variation in microbial biomass and acid phosphatase activity within the growing season. Appl Soil Ecol 22:167-174.

Berner RA (1981) A new geochemical classification of sedimentary environments. J Sed Petrol 51:359-365.

Brito IM and Lemos EE (1982) Evolução geológica e fauna da Lagoa Rodrigo de Freitas, Rio de Janeiro. An Acad Bras Ciênc 54:143-164.

Burton ED, Phillips IR, Hawker DW (2004) Trace metals and nutrients in bottom sediments of the Southport Broadwater, Australia. Mar Poll Bull 48:378-402.

Burton ED, Phillips IR, Hawker DW (2005) Geochemical Partitioning of Copper, Lead, and Zinc in Benthic, Estuarine Sediment Profiles, J of Environ Qual 34:263-273.

Carlucci AF, Craven DB, Robertson DJ, Williams PM (1986) Surface-film microbial populations diel amino acid metabolism, carbon utilization and growth rates. Mar Biol 92:289-297.

Cavalcante RM, Sousa FW, Nascimento RF, Silveira ER, Freire GSS (2009) The impact of urbanization on tropical man- 
groves (Fortaleza, Brazil), evidence from PAH distribution in sediments. J of Environ Manage 91:328-325.

Celis R, Hermosin MC, Cornejo J (2000) Heavy metal adsorption by functionalized clays. Env Sci Tech 34:4593-4599.

Chang IS, Shin PK, Kim BH (2000) Biological treatment of acid mine drainage under sulphate-reducing conditions with solid waste materials as substrate. Wat Res 34:1269-1277.

Corseuil HX, Alvarez PJJ (1996) Natural biorremediation of aquifer material contaminated with gasoline-ethanol mixture. Rev de Microb 27:19-26.

Cui Y, Zhu YG, Zhai RH, Chen DY, Huang YZ, Qiu Y, Liang JZ (2005) Exposure to metal mixtures and human health impacts in a contaminated area in Nanning, China. Env Int 31:784-790.

Cunha-Santino MB, Bianchini Júnior I (2010) Q10 of heterotrophic activity during aerobic decomposition of Utricularia breviscapa and its effect on carbon cycling in a tropical lagoon. Braz J of Bio 70:317-324.

da Silva TF, Azevedo D de A, de Aquino Neto F R (2007) Distribution of polycyclic aromatic hydrocarbons in surface sediments and waters from Guanabara Bay, Rio de Janeiro, Brazil. J Braz Chem Soc 18:628-637.

Dell'Anno A, Mei ML, Pusceddu A, Danovaro R (2002) Assessing the trophic state and eutrophication of coastal biochemical composition of sediment organic matter. Mar Poll Bull 44:611-622.

Dubois M, Gilles A, Hamilton JK, Rebers PA, Smith F (1956) Colorimetric method of determination of sugars and related substances. Anal Chem 28:350-355.

Duran R, Ranchou-Peyruse M, Menuet V, Monperrus M, Bareille G, Gon MS, Salvado JC, Amouroux D, Guyoneaud R, Donard OFX, Caumette P (2008) Mercury methylation by a microbial community from sediments of the Adour Estuary (Bay of Biscay, France). Environ Poll 156:951-958.

Eggleton J and Thomas KV (2004) A review of factors affecting the release and bioavailability of contaminants during sediment disturbance events. Env Int 30:973-980.

Fabiano M and Pusceddu A (1998) Total and hydrolizable particulate organic matter (carbohydrates, proteins and lipids) at a coastal station in Terra Nova Bay (Ross Sea, Antarctica). Polar Biol 19:125-132.

Fabiano M, Danovaro R, Fraschetti S (1995) A three-year time series of elemental and biochemical composition of organic matter in subtidal sediments of the Ligurian Sea (northwestern Mediterranean). Cont Shelf Res 15:1453-1469.

Fischer H, Sachse A, Steinberg CEW, Pusch M (2002) Differential retention and utilization of dissolved organic carbon by bacteria in river sediments. Limn and Ocea 47:1702-1711.

Gerchacov SM and Hatcher PG (1972) Improved technique for analysis of carbohydrates in sediment. Limn and Ocea 17:938-943.

Gilbert O, de Pablo J, Cortina JL, Ayora C (2003) Evaluation of municipal compost/limestone/iron mixtures as filling material for permeable reactive barriers for in-situ acid mine drainage treatment. J of Chem Tech and Biotech 78:489496.

Gsell TC, Holben WE, Ventullo, RM (1997) Characterization of the sediment bacterial community in groundwater discharge zones of an alkaline fen: A seasonal study. App Env Microbiol 63:3111-3118.
Haanstra L, Doelman P (1991) An ecological dose-response model approach to shortand longterm effects of heavy metals on arylsulphatase activity in soil. Biol and Fert of Soil $11: 18-23$.

Haglund A, Lantz P, To E, Tranvik, L (2003) Depth distribution of active bacteria and bacterial activity in lake sediment. Microbiol Eco 46:31-38.

Haglund A, Tornblom E, Bostro B, Tranvik L. (2002) Large diferences in the fraction of active bacteria in plankton, sediments, and biofilm. Microbiol Ecol 43:232-241.

Hartree EF (1972). Determination of protein a modification of the Lowry Method that gives a linear photometric response. Anal Biochem 48:422-427.

Helsel DR, Hirsch RM (1992) Studies in environmental science 49 - Statistical methods in water resources, Amsterdam, Elsevier, $522 \mathrm{p}$.

Hinojosa MB, Carreira JÁ, Garcia-Ruiz R (2004) Soil moisture pre-treatment effects on enzyme activities as indicators of heavy metal-contaminated and reclaimed soils. Soil, Biol. \& Biochem 36:1559-1568.

Houri-Davignon C and Relexans JC (1989) Measurement of actual electron transport system (ETS). Activity in marine sediments by incubation with INT. Env Tech Letter 10:91-100.

Jennings VLK, Rayner-Brandes H, Bird DJ (2001) Assessing chemical toxicity with the bioluminescent Photobacterium (Vibrio fischeri): A comparison of three commercial systems. Wat Res 35:3448-3456.

Kepner J and Pratt JR (1994) Use fluorochromes for direct enumerations of total bacteria in environmental samples: Past and present. Microbiol Rev 58:603-615.

Khairya MA, Kolba M, Mostafab AR, EL-Fiky A, Bahadira M (2009) Risk assessment of polycyclic aromatic hydrocarbons in a Mediterranean semi-enclosed basin affected by human activities (Abu Qir Bay, Egypt) J of Haz Mat 170:389397.

Khan S, Cao Q, Hesham AE-L, Xia, Y, He J-Z (2007) Soil enzymatic activities and microbial community structure with different application rates of $\mathrm{Cd}$ and $\mathrm{Pb}$. $\mathrm{J}$ of Enviro Sci 19:834-840

Kim KT, Ra K, Kim ES, Yim UH, Kim JK (2011) Distribution of Heavy Metals in the Surface Sediments of the Han River and its Estuary, Korea. J of Coast Res. 64:903-907.

Kolmert A and Johnson DB (2001) Remediation of acidic waste waters using immobilised, acidophilic sulfate-reducing bacteria. J of Chem Technol and Biotech 76:836-843.

Kruopiene J (2007) Distribution of Heavy Metals in Sediments of the Nemunas River (Lithuania) Polish J of Environ Stud 16:715-722.

Loureiro DD (2009) Heavy metal inputs evolution to an urban hypertrophic coastal lagoon, Rodrigo De Freitas Lagoon, Rio De Janeiro, Brazil. Env Mon Assessm 159, 577-588.

Macdonald, RW, Harner TT, Fyfe J (2005) Recent climate change in the Arctic and its impact on contaminant pathways and interpretation of temporal trend data. Sci of the Tot Environ 34:25-86.

Magrisso S, Erel Y, Belkin S (2008) Microbial reporters of metal bioavailability. Microbiol Biotech 1:320-330.

Marsh JB and Weinstein DB (1966) Simple charring method for determination of lipids. J of Lipid Res 7:574-576.

McAlister JJ, Smith BJ, Baptista Neto JÁ, Simpson JK (2005) Geochemical distribution and bioavailability of heavy met- 
als and oxalate in street sediments from Rio de Janeiro, Brazil: A preliminary investigation. Environ Geochem and Health 27:429-441.

Medeiros PM, Bícego MC, Castelao RM, Del Rosso C, Fillmann G, Zamboni AJ (2005) Natural and anthropogenic hydrocarbons inputs to sediments to Patos Lagoon Estuary. Braz Environ Int 31:77-87.

Megharaj KVM, Sethunathan N, Naidu R (2003) Bioavailability and toxicity of cadmium to microorganisms and their activities in soil: A review. Advances in Environ Res 8:121-135.

Miskin I, Rhodes G, Lawlor K, Saunders JR, Pickup R (1998) Bacteria in post-glacial freshwater sediments. Microbiol 144:2427-2439.

Moreno JL, Garcia, C, Hernandez T (2003) Toxic effect of cadmium and nickel on soil enzymes and the influence of adding sewage sludge. Eur J of Soil Sci 54:377-386.

Nweke CO, Orji JC (2009) Toxicity of Heavy Metals to Microbial Community of New Calabar River. Nigerian J of Biochem Molec Biol 24:47-53.

Ortega-Morales BO; Santiago-García JL, Chan-Bacab MJ, Moppert X, Miranda-Tello, E, Fardeau ML, Carrero JC, Bartolo-Pérez P, Valadéz-Gonzálezand A. Guezennec J (2007) Characterization of extracellular polymers synthesized by tropical intertidal biofilm bacteria. J of App Microbiol 102:254-264.

Pereira E, Baptista-Neto JÁ, Smith BJ, McAllister JJ (2007) The contribution of heavy metal pollution derived from highway runoff to Guanabara Bay sediments, Rio de Janeiro / Brazil. An Acad Bras Ciênc 79:739-750.

Pérez de Mora A. Madejó E. Burgos P. Cabrera F (2006) Trace element availability and plant growth in a mine-spill contaminated soil Ander assisted natural remediation So Scie of the T Environ 363:28-37.

Perra G, Renzi M, Guerranti C, Focardi SE (2009) Polycyclic aromatic hydrocarbons pollution in sediments: Distribution and sources in a lagoon system (Orbetello, Central Italy). Transit Wat Bull 3:45-58.

Ram MS, Singh L, Suryanarayana MVS, Alam SI (2000) Effect of Iron, Nickel and Cobalt on Bacterial Activity and Dynamics during Anaerobic Oxidation Of Organic Matter. Wat Air and Soil Poll 117:305-312.

Rattan RK, Datta SP, Chhonkar PK (2005) Long-term impact of irrigation with sewage effluents on heavy metal content in soils, crops and groundwater-a case study. Agri Ecol \& Environ 109:310-322.

Rauf A, Javed M, Ubaidullah M, Abdullah S (2009) Assessment of Heavy Metals in Sediments of the River Ravi, Pakistan. Int J Agric Biol 11:197-200.

Reddy GB, Hunt PG, Phillips R, Stone KC, Grubbs A (2000) Treatment of swine wastewater in Marsh-pond-marsh constructed. 7th International Conference on Wetland System for Water Pollution Control, 8 pp.

Rice DL (1982) The detritus nitrogen problem: New observations and perspectives from organic geochemstry. Mar Eco Program Series 9:153-162.
SEMADS (2001) Bacias Hidrográficas e Recursos Hídricos da Macrorregião 2 - Bacia da Baía de Sepetiba. SEMADS (Secretaria de Estado de Meio Ambiente e Desenvolvimento Sustentável), Rio de Janeiro. 79 p.

Silva AAL, Carvalho MAR, Souza SAL, Dias PMT, Filho RGS, Saramago CSM, Bento CAM, Hofer E (2012): Heavy Metal Tolerance ( $\mathrm{Cr}, \mathrm{Ag}$ and $\mathrm{Hg}$ ) In bacteria isolated from sewage Brazilian J. of Microbio. 1620-1631.

Stubberfield LCF and Shaw PJA (1990) A comparison of tetrazolium reduction and FDA hidrolysis with other measures of microbial activity. J of Microbio Methods 12:151-162.

Sun FL, Wang YS, Sun CC, Peng YL, Deng C (2012) Effects of three different PAHs on nitrogen-fixing bacterial diversity in mangrove sediment. Ecotoxicol 21(16):51-60.

Tam NFY, Wang XH, Wong YS (2001) Contamination of polycyclic aromatic hydrocarbons in surface sediments of mangrove swamps. Environ Poll 114:255-263.

Torres JM (1990). Laguna Rodrigo de Freitas. Revista Municipal de Engenharia. Prefeitura da Cidade do Rio de Janeiro, Rio de Janeiro, XLI (1/4):31-63.

Trevors JT (1984). Effect of substrate concentration, inorganic nitrogen, 02 concentration, temperature and $\mathrm{pH}$ on dehydrogenase activity in soil. Wat Res 77:285-293.

Tronczynski J, Munschy C, Héas-Moisan K, Guiot N, Truquet I (2005) Analyse de contaminants organiques (PCB, OCP, HAP) dans les sédiments marins. Méthodes d'analyse en milieu marin. IFREMER, $44 \mathrm{p}$.

Videla HÁ and Herrera LK (2005) Microbiologically influenced corrosion: Looking to the future. Intern Microbiol 8:169180.

Viret H, Pringault O, Duran R (2006) Impact of zinc and nickel on oxygen consumption of benthic microbial communities assessed with microsensors. Sci of the Tot Environ 367:302311.

Vishnivetskaya TA, Mosher JJ, Palumbo AV, Yang ZK, Podar M, Brown SD, Brooks SC, Gu B, Southworth GR, Drake MM, Brandt CC and Elias DA (2011). Mercury and Other Heavy Metals Influence Bacterial Community Structure in Contaminated Tennessee Streams. Appl. Environ. Microbiol., 77(1):302.

Vu B, Chen M, Russell JC, Ivanova EP (2009) Bacterial Extracellular Polysaccharides Involved in Biofilm Formation. Molec 14:2535-2554.

Walkley A and Black IA (1934) An examination of the Degtjareff method of determining soil organic matter and a proposed modification of the chromic acid titration method. Soil Sci 37:29-37.

Wellsbury P, Herbert RA, Parkes RJ (1996) Bacterial activity and production in nearsurface estuarine and freshwater sediments. Microbiol Ecol 19:203-211.

Witt U, Muller RJ, Deckwer WD (1997) Biodegradation behaviour and material properties of aliphatic/aromatic polyesters of commercial importance. J of Environ Poll Degra 15:8189 .

All the content of the journal, except where otherwise noted, is licensed under a Creative Commons License CC BY-NC. 